2. Belcher, M. 1980. Birds of Regina. Special Publication 12, Saskatchewan Natural History Society, Regina.

3. Bent, A.C. 1907-08. Summer birds of southwestern Saskatchewan. Auk 24:407-430 and 25:25-35.

4. Bradshaw, F. 1918, 1920, 1922. Report of the chief game guardian for Saskatchewan.

5. Callin, E.M. 1980. Birds of the Qu'Appelle Valley, 1857 - 1979. Special Publication 13, Saskatchewan Natural History Society, Regina.

6. Godfrey, W.E. 1950. Birds of the Cypress Hills and Flotten Lake regions, Saskatchewan. National Museum of Canada Bull. 120.

7. Godfrey, W.E. 1986. Birds of Canada, revised edition. Ottawa: National Museum of Natural Sciences.

8. Holmes, C.F. 1946. Mockingbird and Lark Sparrow. Blue Jay 4:42.

9. Macoun, J. 1904. Catalogue of Canadian birds, part 3. S.E. Dawson, Ottawa
10. Martin, J.W., and J.R. Parrish, 2000. Lark Sparrow (Chondestes grammacus). In The Birds of North America, No. 488 (A. Poole and F. Gill, eds.). The Birds of North America, Inc., Philadelphia.

11. Potter, L.B. 1923. Notes on birds in southwest Saskatchewan. Condor 25:101-102.

12. Potter, L.B. 1943. Bird notes from south-western Saskatchewan. Canadian Field-Naturalist 58:66-67.

13. Renaud, W.E., and D.E. Renaud. 1975. Birds of the Rosetown-Biggar district, Saskatchewan. Special Publication 9, Saskatchewan Natural History Society, Regina

14. Roy, J.F. 1995. Birds of the Elbow. Special Publication 21, Saskatchewan Natural History Society, Regina

15. Street, M.G. 1965. Lark Sparrow breeding at Nipawin. Blue Jay 23:26-27.

16. Walley, W.J. 1985. Breeding range extension of the Lark Sparrow into westcentral Manitoba. Blue Jay 43:18-24.

\title{
ADDENDUM: THE GREAT BUFFLEHEAD CRASH ${ }^{1}$
}

JAMES K. FINLEY, 10232 Summerset Place, Sidney, BC V8L 4X2

After dealing with some exasperating details, I printed a final copy of "The Great Bufflehead Crash" ${ }^{1}$ and sent it off to the editors of Blue Jay. I also printed a copy for my Foam Lake correspondents, and mailed it on October $31^{\text {st }}$. Next day, I left on a trip into the interior of B.C. to watch - what else - Buffleheads: When I returned a week later, some details and buffleheads had returned to haunt me.

My return to the coast nearly coincided with: a) the sixtieth anniversary of the Great Bufflehead Crash (November $4-5^{\text {th }}$ ), b) the first 
major cold front sweeping over the prairies (November $5^{\text {th }}$ ), and c) a major influx of Buffleheads (November 6-7 th) to their coastal wintering grounds.

A few days later, I received an envelope, postmarked Foam Lake. It contained a clipping from the Wadena News, dated November $1^{\text {st }} 2000$, concerning an eerily-familiar story: "Distressing situations are not reserved solely for the human species, a fact that was borne out in the skies over Wadena on Sunday night. As fog descended with the darkness of the evening, flocks of geese were heard as they passed overhead, traveling to the southwest on their way to Little Quill Lake. Shortly after the noise of the numerous passing flocks had abated, a flock could be heard approaching from the southwest, the opposite direction to which they should have been traveling. Hampered by the fog cover, they had apparently been unable to locate the lake and were convinced that the glow from Wadena's lights was actually Little Quill."

A note on the margin stated that the same thing happened at Foam Lake on the same night! Evidently, the weather conditions that caused the disorientation occurred within the Quill Lakes region. According to the reporter, the ground fog was fairly heavy, but there was a much heavier layer a distance above. The geese circled in confusion for the next few hours until the fog lifted. The reporter said it brought to mind another article in the Wadena News in about 1943 when dozens of ducks and geese mistook the towns' lights for the lake, and were killed when they hit power and telephone lines, trees and buildings. Such a coincidence of events! It seems that the Quill Lakes region must be the Bermuda Triangle of Buffleheads and their clan. These avian disasters, or near disasters, appear to arise from the rare coincidence of several possible events. This congruence of factors includes freeze-up of large sloughs (a function of solar storage capacity), the weather (flights take advantage of the southward flow of dry polar air immediately following a cold front), and time of day (flights are initiated at dusk under clear skies). These factors come together within a restricted window of time on the prairies, around Hallowe'en, when fog gathers in spooky hollows, and the mercury-vapor illumination emanating from small towns beckons like illusory lakes. An invisible flight over the prairies, registered as nocturnal blips on airport radar screens, the mass exodus of Buffleheads is evident in the sharp peak of coastal-bound migrants through U.S. National Wildlife Refuges during the first week of November, ${ }^{2}$ at "surprisingly similar times". ${ }^{3}$

Buffleheads and geese rarely fowl up their flight plans. But when they do, it makes the news. ${ }^{4,5}$

\section{Acknowledgements}

Thanks to Inge Helgason and Ruth Gushulak, keepers of Foam Lake's natural heritage, and to Anna and Ted Leighton, editors.

1. Finley, J.K. 2000. The great Bufflehead crash, 1940. Blue Jay 58: 161-167.

2. Erskine, A.J. 1971. Buffleheads. Canadian Wildlife Service Monograph Series \#4. Information Canada, Ottawa. $240 \mathrm{p}$.

3. Bellrose, F.C. 1976. Ducks, Geese and Swans of North America. Stackpole Books, Harrisburg, Pennsylvania. p 415.

4. Anonymous. 1940. Foam Lake locals. The Western Review. Volume 24 : 45

5. Swallow, H.S. 1941. Rain of ducks at Foam Lake, Saskatchewan. Canadian Field-Naturalist. 55: 130. 